\title{
Heifer nutrient intake during early- and mid-gestation programs adult offspring adiposity and mRNA expression of growth- related genes in adipose depots
}

\author{
Gina C Micke, Tracy M Sullivan, I Caroline McMillen ${ }^{1}$, Sheridan Gentili ${ }^{1}$ and Vivienne E A Perry ${ }^{1}$ \\ School of Veterinary Science, The University of Queensland, Brisbane, St Lucia, Queensland 4072, Australia and \\ ${ }^{1}$ Sansom Institute for Health Research, University of South Australia, Adelaide, South Australia 5000, Australia
}

Correspondence should be addressed to VE A Perry; Email: viv.perry@unisa.edu.au

\begin{abstract}
Changes in maternal nutrient intake during gestation alter IGF receptor abundance and leptin (LEP) mRNA expression in fetal adipose tissue. It is not known whether such changes persist into adult life and whether they are associated with an effect on phenotype. We investigated the effect of high $(\mathbf{2 4 0} \%)$ and low $(\mathbf{7 0} \%)$ levels of recommended daily crude protein intake for beef heifers during the first and second trimesters of gestation on singleton progeny $(n=68)$ : subcutaneous (SC) adipose tissue depth at rump (P8) and rib (RF) sites from 65 until 657 days of age; plasma leptin concentrations from birth until 657 days and expression of IGF1 and IGF2, their receptors (IGF1R and IGF2R) and LEP mRNA in perirenal (PR), omental (OM) and SC adipose tissue at 680 days of age. High-protein diets during the first trimester increased LEP and IGF1 mRNA in PR of males and females, respectively, compared with low-protein diets, and decreased IGF1R mRNA in SC of all progeny but increased RF depth of males between 552 and 657 days. High-protein diets compared with low-protein diets during the second trimester increased IGF1R mRNA in PR and OM of all progeny; LEP mRNA in PR of males; and IGF2 and IGF2R mRNA in OM of all progeny. Conversely, LEP mRNA in OM and IGF2 mRNA in PR of all progeny were decreased following exposure to high- compared with low-protein diets during the second trimester. Heifer diet during gestation has permanent sex- and depot-specific effects on the expression of adipogenic and adipocytokine genes and offspring adiposity.

Reproduction (2011) $141697-706$
\end{abstract}

\section{Introduction}

Adipose tissue has an important regulatory and homeostatic function (Hausman et al. 2009) as well as being a significant contributor to the commercial carcass value of beef cattle (Robinson et al. 2001). Epidemiological studies have demonstrated a strong association between maternal nutrient intake during gestation and the later risk of obesity and development of the metabolic syndrome during adulthood (McMillen \& Robinson 2005). Adipogenesis is induced before birth in a range of species including humans, sheep and cattle, and is regulated by the activation of the insulin-like growth factor (IGF) type 1 receptor (IGF1R) via the binding of IGF1 or insulin (Teruel et al. 1996). During fetal development, the somatotropic axis is regulated by fetal nutrient supply (Holt 2002), which is a function of the interplay between maternal nutrient intake and maternal maturity (Wallace et al. 2005). In the mature animal, hypertrophy and hyperplasia of adipocytes result in changes to adiposity (Gregoire 2001). This process is regulated by the interaction of IGF1 and leptin (LEP), an adipocytokine that controls caloric intake, energy expenditure (Prins 2002, Louveau \& Gondret 2004) and regulates nutritional status effects on reproductive function (Houseknecht et al. 1998). Several studies on the effects of fetal nutrient supply during gestation on adipose tissue development in the sheep have demonstrated that the effects are time- and depot-specific. For example, maternal nutrient restriction during the period of maximal placental development results in up-regulation of IGF1R and IGF2R mRNA abundance in fetal perirenal (PR) adipose tissue (Bispham et al. 2003), but placental restriction due to carunclectomy prior to mating results in decreased expression of IGF1 and LEP mRNA in PR (Duffield et al. 2008). Conversely, maternal overfeeding during the final month of pregnancy results in up-regulation of $\angle E P$ mRNA expression in fetal PR and subcutaneous (SC) adipose tissue (Muhlhausler et al. 2007a). However, the long-term effects of prenatal nutrition on IGF and LEP mRNA expression in adipose tissue of mature offspring are not clear.

Pasture protein content can vary tenfold throughout the year (Schut et al. 2010). In northern Australia, protein supplementation of breeder herds is necessary to 
maintain body condition during the dry season (Bortolussi et al. 2005), while in Southern Australia, breeder cattle often graze winter and spring pastures that provide greater than the recommended level of protein (Walsh \& Birrell 1987). We have previously reported that male fetuses exposed to a low level of maternal nutrient intake during the first trimester were heavier throughout the postweaning period compared with their high-nutrient exposed counterparts. Females, on the other hand, exposed to a high level of maternal nutrient intake during the first trimester of gestation were heavier just prior to slaughter (Micke et al. 2010a). Since adipose tissue is an important contributor to traits of economic importance to the beef breeding enterprise such as neonatal survival, carcass value and reproductive performance. We investigated the effect of heifer nutrient intake during the first and second trimesters of gestation on the relative expression of IGF1, IGF2, IGF1R, IGF2R and LEP mRNA in PR, omental (OM) and SC adipose tissue of their offspring at 680 days (d) of age. We hypothesized that feeding maternal diets low in nutrients during either the first or second trimester of gestation would result in a lower expression of IGF1, IGF2 and LEP mRNA and a higher expression of IGF1R and IGF2R mRNA in the adipose tissue of mature progeny compared with adipose tissue from progeny exposed to maternal diets high in nutrients during these periods.

\section{Results}

\section{Postnatal growth and SC adipose tissue accumulation}

We have previously reported that in this cohort progeny that were exposed to high levels of maternal nutrition during T2 were $8.3 \%$ heavier at birth $(\mathrm{HH}+\mathrm{LH}$ $=33.05 \pm 0.81 \mathrm{~kg}$ ) compared with their counterparts exposed to low levels of maternal nutrition $(\mathrm{HL}+\mathrm{LL}$ $=30.76 \pm 0.59 \mathrm{~kg} ; P=0.03$ ) (Micke et al. 2010b). From 191 to $657 \mathrm{~d}$, however, males that were exposed to low levels of maternal nutrition during T1 (LH+LL) were $\sim 4 \%$ heavier than their counterparts exposed to high levels of maternal nutrition $(\mathrm{HH}+\mathrm{HL} ; P=0.04$ ) (Micke et al. 2010a). In contrast, females exposed to a high level of maternal nutrition during $\mathrm{T} 1$ had $6.9 \%$ heavier carcasses $(\mathrm{HH}+\mathrm{HL}: 334.53 \pm 5.54 \mathrm{~kg})$ compared with their low-nutrient exposed counterparts $(\mathrm{LL}+\mathrm{LH}$ : $312.92 \pm 6.82 \mathrm{~kg} ; P=0.04$ ) (Micke et al. 2010a). Males were heavier than females throughout the study $(P<0.01)$.

In the current study, the depth of RF adipose tissue from 65 until $657 \mathrm{~d}$ tended to depend on maternal nutrition during $\mathrm{T} 1 \times$ time $\times \operatorname{sex}(P=0.07)$, and we therefore analyzed each sex separately. For males, the effect of maternal nutrition during T1 changed with time $(P<0.01)$ as RF depth was $67 \%$ greater from 552 to 657 $\mathrm{d}$ following exposure to a high $(\mathrm{HH}+\mathrm{HL})$ compared to low $(\mathrm{LH}+\mathrm{LL})$ level of maternal nutrition during the first trimester $(P<0.01$; Fig. 1, Panel A). There was no effect of maternal nutrition during $\mathrm{T} 1$ on RF depth of females. There was no effect of maternal nutrition during $\mathrm{T} 1$ or T2, sex or gestation length on RF depth relative to liveweight, P8 depth or P8 depth relative to liveweight from 65 until $657 \mathrm{~d}$.

\section{$P R$ adipose tissue $m R N A$ expression}

Expression of IGF1 mRNA in PR adipose tissue depended on the effect of maternal nutrition during $T 1 \times$ sex $(P=0.05)$, and we therefore analyzed each sex separately. For males, there was no effect of maternal nutrition during T1 (data not shown), but for females, those exposed to a high $(\mathrm{HH}+\mathrm{HL})$ compared with low $(\mathrm{LL}+\mathrm{LH})$ level of maternal nutrition during the first trimester had $42 \%$ greater IGF1 mRNA expression in PR $(P=0.05)$. There was no effect of maternal nutrition during the second trimester on IGF1 mRNA expression in PR adipose tissue of males or females (data not shown).

Expression of IGF1R mRNA in PR adipose tissue of all progeny was $50 \%$ greater following exposure to a high $(\mathrm{HH}+\mathrm{LH})$ compared with low $(\mathrm{LL}+\mathrm{HL})$ level of maternal nutrition during the second trimester of gestation $(P<0.01$; Fig. 2 , Panel A). There was no effect of maternal nutrition during the first trimester on IGF1R mRNA expression in PR adipose tissue (data not shown).

Expression of IGF2 mRNA in PR adipose tissue of all progeny was $20 \%$ greater following exposure to low $(\mathrm{LL}+\mathrm{HL})$ compared with high $(\mathrm{HH}+\mathrm{LH})$ levels of maternal nutrition during the second trimester of gestation ( $P=0.04$; Fig. 2, Panel B) but there was no effect of maternal nutrition during T1 (data not shown).
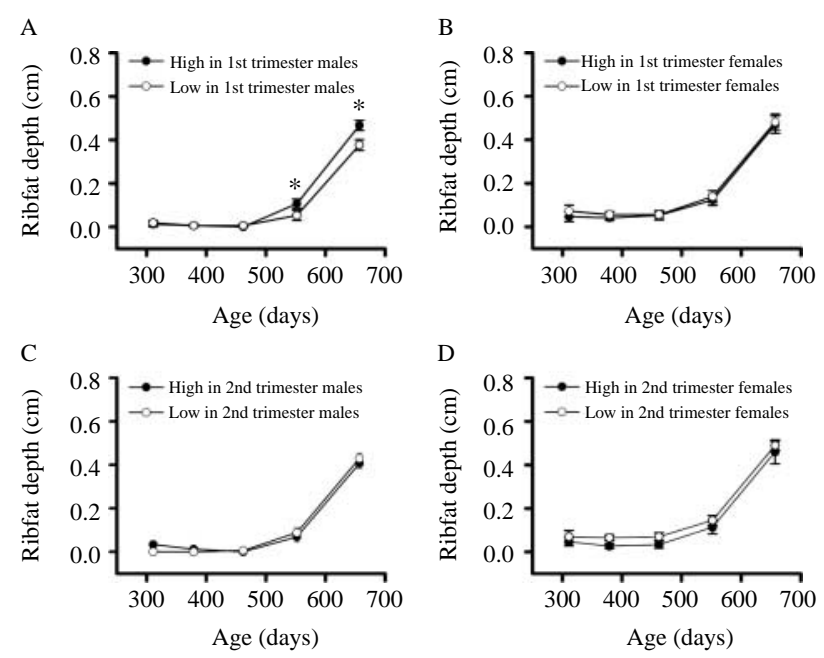

Figure 1 Depth of adipose tissue between the 12th and 13th ribs of male (Panels A and C) and female (Panels B and D) progeny during the postweaning period by trimester treatment group. Asterisks denote a significant effect of maternal nutrition $(P<0.01)$. 


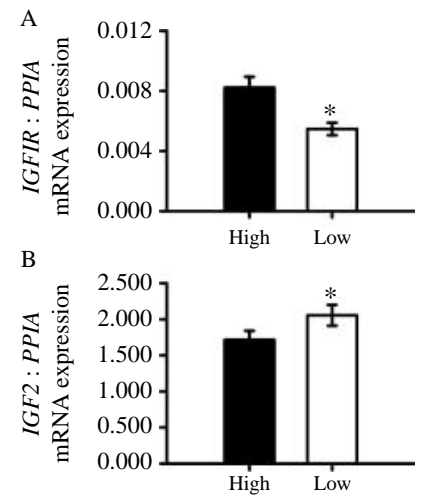

Figure 2 The expression of IGF1R (Panel A) and IGF2 (Panel B) mRNA relative to PPIA mRNA expression in perirenal adipose tissue of cattle at $680 \mathrm{~d}$ following exposure to maternal diets high or low in nutrients during the second trimester of gestation. Asterisks denote a significant effect of maternal nutrition $(P<0.05)$.

Expression of $L E P$ mRNA in the PR depot depended on maternal nutrition during $\mathrm{T} 1 \times \operatorname{sex}(P=0.02)$ and maternal nutrition during $\mathrm{T} 2 \times \operatorname{sex}(P=0.02)$ and we therefore analyzed each sex separately. Males exposed to a high level of maternal nutrition during either the first $(\mathrm{HH}+\mathrm{HL} ; P<0.01)$ or second $(\mathrm{HH}+\mathrm{LH} ; P=0.04)$ trimester of gestation had 116 and $64 \%$ greater LEP mRNA expression respectively compared with their lownutrient exposed counterparts (Fig. 3). There was no effect of maternal nutrition during $\mathrm{T} 1$ or T2 on PR LEP mRNA expression in females (data not shown). There was no effect of maternal nutrition during T1 or T2 on IGF2R mRNA expression in PR adipose tissue (data not shown). There was no sex or gestation length effect on IGF1, IGF1R, IGF2, IGF2R or LEP mRNA expression in $P R$ adipose tissue (data not shown).

\section{Omental adipose tissue mRNA expression}

Expression of IGF1R $(P=0.02)$, IGF2 $(P=0.02)$ and IGF2R $(P=0.03)$ mRNA in OM adipose tissue were 24 , 27 and $17 \%$ greater respectively for progeny exposed to a high $(\mathrm{HH}+\mathrm{LH})$ compared with low $(\mathrm{LL}+\mathrm{HL})$ level of maternal nutrition during the second trimester (Fig. 4, Panels A-C). In contrast, LEP mRNA expression in OM adipose tissue was $28 \%$ greater in progeny that were exposed to low $(\mathrm{LL}+\mathrm{HL})$ compared with high $(\mathrm{HH}+\mathrm{LH})$ level of maternal nutrition during the second trimester of gestation ( $P=0.04$; Fig. 4, Panel D). Females had greater IGF1 mRNA expression compared with males $(P=0.02)$ in $\mathrm{OM}$ adipose tissue. There was no effect of gestation length on IGF1, IGF1R, IGF2, IGF2R or LEP mRNA expression in $\mathrm{OM}$ adipose tissue. There was no effect of maternal nutrition during trimester one on the expression of IGF1, IGF1R, IGF2, IGF2R and LEP mRNA expression, nor of trimester two maternal nutrition on IGF1 mRNA expression (data not shown).

\section{SC adipose tissue $\boldsymbol{m R N A}$ expression}

Expression of IGF1R mRNA in SC adipose tissue was $29 \%$ greater for progeny that were exposed to a low $(\mathrm{LL}+\mathrm{LH})$ compared with high $(\mathrm{HH}+\mathrm{HL})$ level of maternal nutrition during the first trimester of gestation $(P=0.02$; Fig. 5). There were no further effects of maternal nutrition during trimester one or two on the expression of the genes measured (data not shown). Males had greater IGF2 $(P=0.04)$ and IGF2R $(P<0.01)$ mRNA expression in SC adipose tissue compared with females, but there was no effect of gestation length on expression of any of the genes measured in SC adipose tissue.

\section{Progeny plasma leptin}

There was no effect of maternal nutrition during T1 or T2, or of gestation length, on plasma leptin concentrations in progeny from birth to $657 \mathrm{~d}(P>0.1)$. Females had higher plasma leptin than males throughout the study $(P<0.01$; Fig. 6).

\section{Relationship between progeny plasma IGF concentrations with IGF and LEP mRNA expression in adipose tissue}

Plasma concentrations of IGF1, IGF2 and tIGFBP have been reported (Micke et al. 2010a). Significant correlation coefficients for associations between progeny plasma concentrations of IGF1, IGF2 and tIGFBP from birth to $657 \mathrm{~d}$ with expression of IGF1, IGF1R, IGF2, IGF2R and LEP mRNA in PR, OM and SC adipose tissue are shown in Table 1.

\section{Discussion}

This study describes the long-term changes in IGF and LEP mRNA expression in progeny $\mathrm{PR}, \mathrm{OM}$ and $\mathrm{SC}$ adipose tissue, and the relationship to the progression of SC adiposity over time, following exposure to two levels of maternal nutrition during gestation in the bovine.

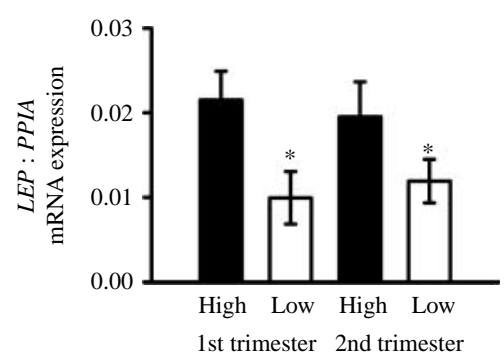

Figure 3 The expression of $L E P$ mRNA relative to PPIA mRNA expression in perirenal adipose tissue of males at $680 \mathrm{~d}$ following exposure to maternal diets high or low in nutrients during the first and second trimesters of gestation. Asterisks denote a significant effect of maternal nutrition between same trimester treatment groups $(P<0.05)$. 

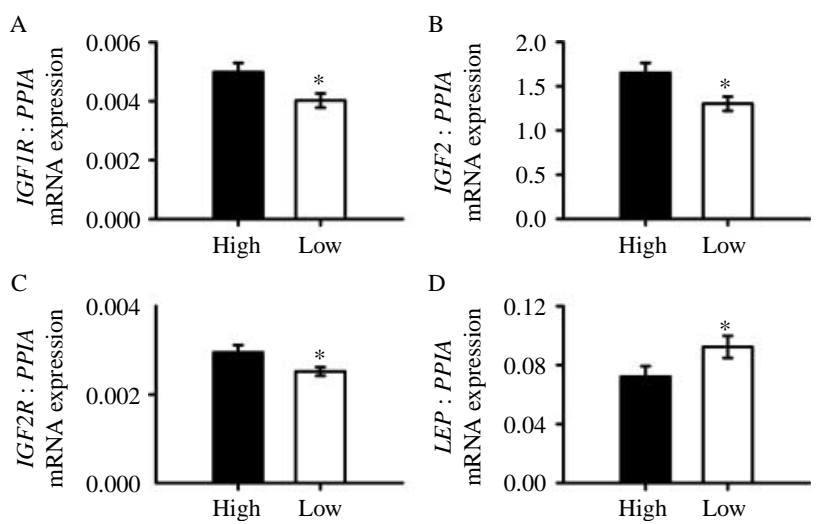

Figure 4 The expression of IGF1R (Panel A), IGF2 (Panel B), IGF2R (Panel C) and LEP (Panel D) mRNA relative to PPIA mRNA expression in omental adipose tissue of cattle at $680 \mathrm{~d}$ following exposure to maternal diets high or low in nutrients during the second trimester of gestation. Asterisks denote a significant effect of maternal nutrition $(P<0.05)$.

The main findings are that the effects of maternal diet during the first two trimesters of gestation on expression of IGF1, IGF1R, IGF2, IGF2R and LEP mRNA in the progeny are depot-specific. This is consistent with there being depot-specific responses of preadipocytes to exogenous factors that regulate preadipocyte differentiation (Soret et al. 1999). In our study, PR adipose tissue was susceptible to the programming effects of maternal nutrient intake during the first and second trimesters of gestation, whereas OM adipose tissue was only susceptible during the second trimester. SC adipose tissue was susceptible to the programming effects of maternal nutrient intake during the first trimester of gestation but in a manner which was opposite to either PR or OM adipose tissue. Despite PR and OM adipose tissue being susceptible to the programming effects during the same period of gestation and $I G F 1 R$ being up-regulated by high levels of maternal nutrient intake during the second trimester in both depots, the expression of IGF2 and $L E P$ exhibited differential responses in each depot (see Table 2).

\section{Nutrition}

There was a 3.3- to 3.6-fold difference in CP content and 1.2- to 1.3-fold difference in energy content between high- and low-group diets, with both groups receiving above the recommended National Research Council (NRC) energy requirements. The degradable intake protein (DIP) balance during the first trimester was $206 \mathrm{~g} /$ day for the high-protein diet group compared with $-345 \mathrm{~g} /$ day for the low-protein diet group and, similarly during the second trimester, the DIP balance for the highprotein diet group was $214 \mathrm{~g} /$ day compared with $-464 \mathrm{~g} /$ day for the low-protein diet group. Therefore, the difference in $\mathrm{CP}$ between the high- and low-protein diets was much greater than that of energy and the negative DIP balance for the low-protein diet group in both the first and second trimesters, which clearly demonstrates that protein intake was restricted. Although the difference in protein levels between the high (in excess of NRC requirements) and low (below NRC recommended requirements) treatment group diets was large, both the high and low treatment group diets had protein contents that are commonplace under Australia grazing conditions (Schut et al. 2010). Thus, the diets used in the current study would be considered relatively normal for breeder herds grazing Australian pastures. Considering the role of protein, especially in respect to the amino acid arginine, in placental angiogenesis and fetal growth (Kwon et al. 2004), and the much greater difference in protein compared with energy intake, the differences observed in our study due to the effects of maternal nutrition during the first and second trimesters of gestation are likely attributable to the effects of protein rather than energy intake. It is possible, however, that the over-supply of energy to heifers in the low-protein group during either trimester one or two may have dampened the effects of feeding low-protein diets. In sheep, overfeeding during late gestation increased offspring lipid accumulation in PR and SC adipocytes (Muhlhausler et al. 2007a), a change that may have been due to increased expression of LEP (Muhlhausler et al. 2007a) and adipogenic genes (Muhlhausler et al. 2007b). We consider there to be minimal differential environmental effects upon the developing fetus and thus postnatal outcomes measured in the progeny as the heifers in our study were artificially inseminated (AI) on the same day, housed under the same environmental conditions and calved over a short period.

In beef production, as in other production systems that suckle their young for a defined period, effects of prenatal nutrition may include an impact upon lactation. We have previously reported that milk intake was lower $(P=0.02)$ for progeny of heifers that received highcompared with low-protein diets during the first trimester and that milk protein content was also affected by maternal protein intake during the first trimester of gestation (Sullivan et al. 2009b). The absence of any significant correlations between IGF mRNA expression

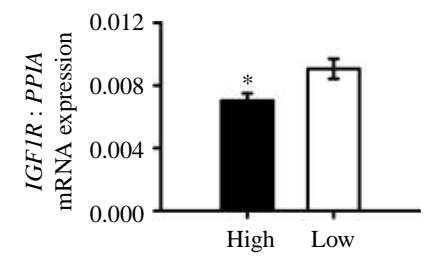

Figure 5 The expression of IGF1R mRNA relative to expression of PPIA mRNA in subcutaneous adipose tissue of cattle at $680 \mathrm{~d}$ following exposure to maternal diets high or low in nutrients during the first trimester of gestation. Asterisks denote a significant effect of maternal nutrition $(P<0.05)$. 


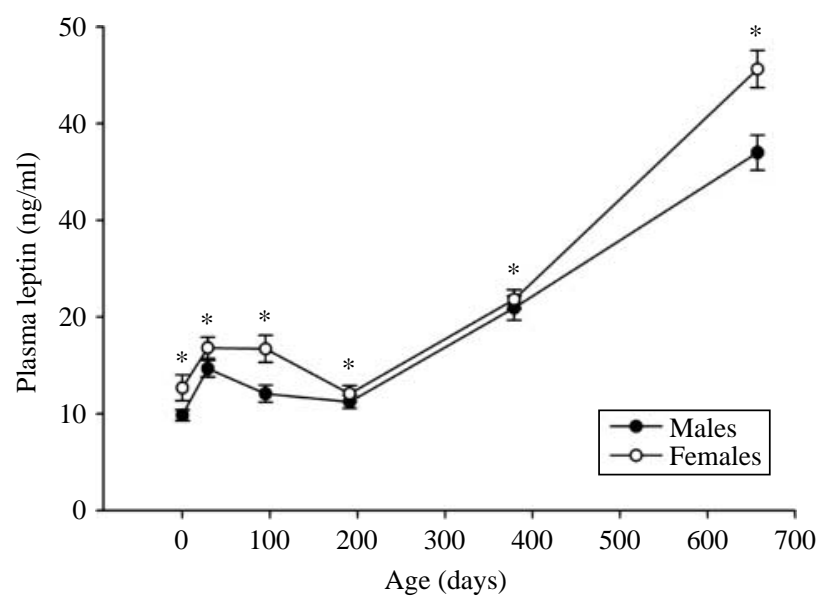

Figure 6 Plasma leptin concentrations of male and female progeny from birth until 657 days of age. ${ }^{*} P<0.01$.

and milk production (data not shown) suggests that differences in nutritional intake during the pre-weaning period did not confound our results; however, crossfostering studies would be required to confirm this. There is a well-established relationship between current nutritional status and circulating IGF concentrations during the postnatal period. Therefore, the lack of a consistent association between adipose tissue mRNA expression and concentrations of IGF1, IGF2 and tIGFBP in progeny plasma suggests that postnatal nutrient intake did not affect mRNA expression in adipose tissue. This finding also supports that the observed changes to mRNA expression were likely of fetal rather than postnatal origin. Interestingly, the significant correlation between IGF1 mRNA expression in SC adipose tissue and plasma IGF1 concentrations suggests that this depot may be a key source of endocrine IGF1 during the postnatal period while the perirenal depot contributes to the clearance of IGF2 from circulation.

\section{Changes to gene expression affecting neonatal survival and adiposity}

Our results suggest that maternal nutrient intake during the first and second trimesters of gestation may affect the thermoregulatory capacity of the neonate due to its effect on expression of IGF1 and IGF1R mRNA in PR adipose tissue. The PR depot is the largest depot of brown adipose tissue in the newborn calf and plays a fundamental role in neonatal thermogenesis and survival prior to its transition to a white adipose storage depot by the end of the first month of life (Clarke et al. 1997). The successful conversion of preadipocytes to mature lipidcontaining adipocytes requires IGF1 (Smith et al. 1988, Gregoire et al. 1998). Up-regulation of IGF1 mRNA in females following exposure to maternal diets high in nutrients during the first trimester, combined with increased tissue sensitivity to the effects of IGF1 via increased IGF1R mRNA, may have enhanced progeny PR adipocyte cell number and, therefore, tissue lipid storage capacity. Importantly, this hypothesis is supported by the concurrent increase in LEP mRNA expression in PR adipose tissue of males exposed to a high level of maternal nutrient intake during the second trimester being also of heavier in birth weight than their low-nutrient exposed counterparts (Micke et al. 2010b). This is because LEP mRNA expression is directly associated with fetal growth (Duffield et al. 2008), fetal weight (Yuen et al. 1999) and level of maternal nutrient intake during gestation (Muhlhausler et al. 2007a).

Table 1 Correlation coefficients for associations of significance between progeny plasma IGF1, IGF2, total IGFBP (tIGFBP) and leptin from birth to $657 \mathrm{~d}$ and the relative expression of IGF1, IGF1R, IGF2, IGF2R and LEP mRNA in perirenal (PR), omental (OM) and subcutaneous (SC) adipose tissue at $680 \mathrm{~d}$ of age.

\begin{tabular}{|c|c|c|c|c|c|c|c|}
\hline & \multirow[b]{2}{*}{$\begin{array}{c}\text { Progeny } \\
\text { plasma }(\mathrm{ng} / \mathrm{ml})\end{array}$} & \multicolumn{6}{|c|}{ Age (days) } \\
\hline & & $0 \mathrm{~d}$ & $29 d$ & $95 \mathrm{~d}$ & $191 \mathrm{~d}$ & $379 d$ & $657 d$ \\
\hline \multicolumn{8}{|l|}{ SC mRNA expression } \\
\hline \multirow[t]{3}{*}{ IGF1 } & IGF1 & -0.0947 & 0.1261 & 0.0771 & 0.1220 & 0.1628 & $0.3511^{*}$ \\
\hline & tIGFBP & 0.0125 & 0.0950 & 0.0449 & 0.1928 & $0.2636^{+}$ & $0.3483^{*}$ \\
\hline & Leptin & -0.0858 & $0.2875^{+}$ & 0.1122 & -0.0244 & -0.0165 & 0.0265 \\
\hline IGF1R & tIGFBP & $0.3123^{\dagger}$ & 0.0906 & 0.0165 & 0.0491 & 0.1453 & $0.2715^{\dagger}$ \\
\hline \multirow[t]{2}{*}{ IGF2 } & IGF1 & 0.0080 & 0.1889 & 0.1212 & 0.1805 & $0.2691^{\dagger}$ & 0.1990 \\
\hline & tIGFBP & $0.3823^{*}$ & 0.1466 & $0.2766^{+}$ & 0.1945 & 0.1559 & $0.2968^{+}$ \\
\hline$I G F 2 R$ & tIGFBP & $0.2599^{\dagger}$ & 0.0553 & 0.0952 & 0.0802 & 0.1412 & 0.2042 \\
\hline$L E P$ & Leptin & 0.1900 & $0.2690^{+}$ & -0.1185 & -0.0189 & $-0.2509^{\dagger}$ & 0.1808 \\
\hline \multicolumn{8}{|l|}{ PR mRNA expression } \\
\hline IGF1 & IGF2 & $-0.2794^{+}$ & -0.1936 & -0.0036 & 0.0149 & 0.0023 & $-0.3209^{+}$ \\
\hline$I G F 1 R$ & IGF2 & 0.0035 & -0.0816 & -0.2141 & -0.0354 & -0.1199 & $-0.2883^{\dagger}$ \\
\hline \multirow[t]{2}{*}{$L E P$} & tIGFBP & 0.0292 & $0.3263^{+}$ & 0.1073 & 0.1214 & $0.2215^{\ddagger}$ & 0.0791 \\
\hline & Leptin & -0.0047 & $0.2409^{\neq}$ & 0.0181 & $0.4007^{*}$ & 0.1951 & 0.0785 \\
\hline $\begin{array}{l}\text { OM mRNA expression } \\
\text { IGF1 }\end{array}$ & tIGFBP & $0.2767^{\dagger}$ & -0.0657 & -0.0761 & -0.0777 & -0.104 & 0.0386 \\
\hline
\end{tabular}

Probability is indicated by $* P<0.01 ;{ }^{+} P<0.05 ;{ }^{\ddagger} P<0.1$. 
Table 2 Summary of significant effects of maternal nutrient intake during the first and second trimesters of gestation on progeny postnatal phenotype and relative expression of IGF1, IGF1R, IGF2, IGF2R and LEP mRNA in perirenal (PR), omental (OM) and subcutaneous (SC) adipose tissue of male (M) and female (F) progeny at $680 \mathrm{~d}$.

\begin{tabular}{|c|c|c|c|c|c|c|c|}
\hline \multirow[b]{2}{*}{ Trait } & \multirow[b]{2}{*}{ Trimester } & \multirow{2}{*}{$\begin{array}{l}\text { Treatment } \\
\text { group effect }\end{array}$} & \multirow[b]{2}{*}{ Sex } & \multicolumn{2}{|c|}{ Mean \pm s.E.M. } & \multirow[b]{2}{*}{ Greater (\%) } & \multirow{2}{*}{$\begin{array}{c}P \text { value of trimester } \\
\text { treatment } \\
\text { group effect }\end{array}$} \\
\hline & & & & High & Low & & \\
\hline \multicolumn{8}{|l|}{ Phenotype } \\
\hline \multirow[t]{2}{*}{ Postweaning weight } & $1 \mathrm{st}$ & Low $>$ high & M & & Average & 4.1 & 0.04 \\
\hline & $1 \mathrm{st}$ & High $>$ low & $\mathrm{F}$ & & Average & 3.2 & 0.07 \\
\hline Carcass weight (kg) & $1 \mathrm{st}$ & High $>$ low & $\mathrm{F}$ & $334.5 \pm 5.5$ & $312.9 \pm 6.8$ & 6.9 & 0.04 \\
\hline Rib fat depth (552-657 d) & $1 \mathrm{st}$ & High $>$ low & M & & Average & 67 & $<0.01$ \\
\hline Birth weight (kg) & $2 n d$ & High $>$ low & $M+F$ & $33.1 \pm 0.8$ & $30.6 \pm 0.6$ & 8.3 & 0.03 \\
\hline \multicolumn{8}{|l|}{ PR mRNA expression } \\
\hline IGF1 & $1 \mathrm{st}$ & High $>$ low & $\mathrm{F}$ & $0.06 \pm 0.007$ & $0.04 \pm 0.004$ & 42 & 0.05 \\
\hline$L E P$ & $1 \mathrm{st}$ & High $>$ low & M & $0.02 \pm 0.003$ & $0.010 \pm 0.003$ & 116 & $<0.01$ \\
\hline IGF1R & $2 \mathrm{nd}$ & High $>$ low & $M+F$ & $0.008 \pm 0.001$ & $0.005 \pm 0.0004$ & 50 & $<0.01$ \\
\hline$L E P$ & 2 nd & High $>$ low & M & $0.02 \pm 0.004$ & $0.01 \pm 0.003$ & 64 & 0.04 \\
\hline IGF2 & 2 nd & Low $>$ high & $M+F$ & $1.7 \pm 0.1$ & $2.1 \pm 0.1$ & 20 & 0.04 \\
\hline \multicolumn{8}{|l|}{ OM mRNA expression } \\
\hline IGF1R & 2nd & High $>$ low & $M+F$ & $0.005 \pm 0.0003$ & $0.004 \pm 0.0002$ & 24 & 0.02 \\
\hline IGF2 & 2nd & High $>$ low & $M+F$ & $1.7 \pm 0.1$ & $1.3 \pm 0.08$ & 27 & 0.02 \\
\hline IGF2R & $2 n d$ & High $>$ low & $M+F$ & $0.0030 \pm 0.0002$ & $0.0025 \pm 0.0001$ & 17 & 0.03 \\
\hline$L E P$ & 2nd & Low $>$ high & $M+F$ & $0.07 \pm 0.007$ & $0.09 \pm 0.007$ & 28 & 0.04 \\
\hline \multicolumn{8}{|l|}{ SC mRNA expression } \\
\hline$I G F 1 R$ & $1 \mathrm{st}$ & Low $>$ high & $M+F$ & $0.007 \pm 0.0005$ & $0.009 \pm 0.0006$ & 29 & 0.02 \\
\hline
\end{tabular}

The concomitant up-regulation of IGF2 mRNA expression in PR adipose tissue following exposure to maternal diets low in nutrients during the second trimester of gestation may reflect a compensatory response by the nutrient-restricted fetus to promote fat deposition and consequent thermogenic capacity, enhancing neonatal survival. However, continued restriction of maternal nutrient supply throughout the second trimester may have limited the ability of the fetus to increase lipid storage as indicated by their comparatively lower $L E P$ mRNA expression, despite the provision of adequate nutrients during the final trimester.

The increased expression of IGF1R, IGF2 and IGF2R mRNA in OM adipose tissue following exposure to high nutrient diets during the second trimester of gestation suggests an increased rate of proliferation and differentiation of preadipocytes to mature adipocytes, as observed in the PR depot. Given that LEP mRNA expression was lower in these same animals, we suggest that despite the potential for a greater number of omental adipocytes available for lipid storage, the amount of lipid stored per cell may have been less than their low-nutrient exposed counterparts. The contrasting effect of second trimester maternal nutrient supply on $L E P$ mRNA expression of OM compared with $P R$ adipocytes may represent the higher preference of $P R$ adipose tissue for nutrient partitioning due to its essential role in neonatal survival. However, as OM adipose tissue becomes the largest visceral depot during postnatal life (Cianzio et al. 1982) and is more metabolically active than SC adipose tissue (Wajchenberg 2000), changes to OM adipose tissue development may have profound effects on their postnatal metabolism and adipose tissue distribution.

\section{Long-term effects of prenatal nutrition on postnatal adiposity}

Exposure to maternal diets low in nutrients during the first trimester of gestation resulted in the expected up-regulation of IGF1R mRNA expression in SC adipose tissue of all progeny, but rib site fat depth was greater in males exposed to high maternal nutrient intake in the first trimester despite these same animals being lighter in weight during the post-weaning period (Micke et al. 2010a). Reports on the effects of maternal nutrient restriction during gestation on progeny SC fat deposition in the postnatal period are conflicting (Greenwood et al. 2006, Stalker et al. 2006, Ford et al. 2007, Underwood et al. 2008, Larson et al. 2009). As the difference in SC fat depth of males in our study was present prior to but not at slaughter (Micke et al. 2010a), it may indicate that the phenotypic difference observed was transient in nature or too small to accurately reflect postnatal adiposity.

This study has demonstrated long-term effects of maternal nutrient intake during the first two trimesters of gestation on expression of IGF and LEP genes in progeny adipose tissue that are depot- and sex-specific, a finding that agrees with previous studies (Montague et al. 1997, Gardan et al. 2006). These changes were not associated with measured commercially important phenotypic changes but may represent fetal adaptations to the nutrient-restricted in utero environment that assists with adaptation and survival in the early neonatal period. Furthermore, the observed changes in the expression of IGF and LEP may be associated with long-term effects on phenotype of cattle that are intensively fed for longer periods of time. Both of these 
production traits warrant further investigation. Both of these production traits are of vital economic importance to the beef industry and warrant further investigation.

\section{Materials and Methods}

All procedures were performed with the prior approval of, and in accordance with, The University of Queensland Animal ethics committee (approval number SVS/716/06/MLA/AACO) and the Institute of Medical and Veterinary Science (approval number UniSA 07_07).

\section{Animals, experimental design and nutrition}

The study utilized a two-by-two factorial design to determine the effects of variations in pasture protein content encountered by gestating breeder herds managed under Australian grazing conditions. The crude protein contents of diets $\sim 4 \%$ (low) and $13 \%$ (high) on a dry matter basis and were representative of reported variations of $1-17 \%$ in legume-based pastures (Schut et al. 2010). The two-by-two factorial design allowed investigation into the interaction effects of high and low levels of recommended dietary protein intake during gestation of the beef heifer.

Study animals are the singleton progeny $(n=68)$ of composite breed beef heifers ( $\mathrm{CBX}=1 / 2$ Senepol $\times 1 / 4$ Brahman $\times 1 / 4$ Charolais; $n=85$ and BeefX $=1 / 2$ Senepol $\times 1 / 4$ Brahman $\times 1 / 8$ Charolais $\times 1 / 8$ Red Angus; $n=35$ ) that were Al with frozen semen from a single sire to calve at $\sim 3$ years of age (Micke et al. 2010b). Dams were divided into four treatment groups on the first day of $\mathrm{Al}$ according to stratification by weight within each composite genotype. The four treatment groups determined the level of crude protein (CP) fed to each heifer during the first ( $\mathrm{T} 1=0-93 \mathrm{~d}$ ) and second (T2 =94-180 d) trimesters of gestation, i.e. high high $(\mathrm{HH}=$ high level of $\mathrm{CP}$ for $\mathrm{T} 1$ and $\mathrm{T} 2)$, high low $(\mathrm{HL}=$ high level of $\mathrm{CP}$ for $\mathrm{T} 1$ and low level of $\mathrm{CP}$ for $\mathrm{T} 2$ ), low high ( $\mathrm{LH}=$ low level of $\mathrm{CP}$ for $\mathrm{T} 1$ and high level of CP for T2) and low low ( $L L=$ low level of $\mathrm{CP}$ for $\mathrm{T} 1$ and T2). All heifers received the same ration from $181 \mathrm{~d}$ until parturition. Details of heifer diets are shown in Table 3. Heifers were individually stall fed until parturition. Seventy-one heifers delivered live calves, gestation length $286 \pm 0.5$ d; range $=278-298 \mathrm{~d}$ (Sullivan et al. 2009a). Three progeny were removed from the study after birth: one due to mis-mothering; one pre-weaning from sudden death of unknown causes; and one post-weaning from death due to misadventure. This resulted in 68 progeny distributed across four treatment groups at the completion of the study as follows: $\mathrm{HH}=15 ; \mathrm{HL}=18$; $\mathrm{LH}=16 ; \mathrm{LL}=19$. No treatments were applied to the progeny. Hereafter, all ages refer to the average age of progeny on the day of sampling.

Postnatally, progeny remained with their mothers on improved and native pastures until weaning at $191 \mathrm{~d}$ in accordance with standard beef herd management practice (Meat-and-Livestock-Australia 2004). They were supplemented daily with whole cotton seed (Gossypium spp.) allocated at $1 \mathrm{~kg} /$ animal while grazing native pastures until $401 \mathrm{~d}$. From $401 \mathrm{~d}$, they were managed as part of a larger group of yearling cattle at Surat, Queensland $\left(27^{\circ} 16^{\prime} \mathrm{S}, 149^{\circ} 07^{\prime} \mathrm{E}\right)$ due to unforeseen drought conditions at their property of origin. Each animal was allocated $20 \mathrm{~kg} / \mathrm{d}$ of a silage-based ration as feed. The ration was $40.7 \%$ dry matter and consisted of $85 \%$ corn silage (Zea mays), 12\% whole cottonseed (Gossypium spp.) and 3\% vitamin and mineral mix. Progeny commenced an intensive feedlot finishing program on $541 \mathrm{~d}$ at Dalby, Queensland $\left(27^{\circ} 18^{\prime} \mathrm{S}, 151^{\circ} 26^{\prime} \mathrm{E}\right)$, where they remained as one group in their own feedlot pen and were fed commercial feedlot rations prior to commercial slaughter at $680 \mathrm{~d}$. Male and female progeny remained together in the same management group at all times throughout the study.

Males were castrated at $153 \mathrm{~d}$ in accordance with standard beef herd management practice (Newman 2007). All progeny were vaccinated against clostridial diseases and leptospirosis (Ultravac 7 in 1: Pfizer Animal Health, West Ryde, NSW, Australia) on 65 and $123 \mathrm{~d}$ with a third clostridial vaccine given on $544 \mathrm{~d}$ (Ultravac 5 in 1: Pfizer Animal Health). On 379 and $544 \mathrm{~d}$, all progeny were vaccinated against Bovine herpesvirus

Table 3 Details of 'high' and 'low' treatment group daily rations fed to dams during each trimester of gestation ${ }^{\mathrm{a}}$.

\begin{tabular}{|c|c|c|c|c|c|}
\hline \multirow[b]{2}{*}{ Item } & \multicolumn{2}{|c|}{ Trimester 1 (1-93 d) } & \multicolumn{2}{|c|}{ Trimester 2 (94-180 d) } & \multirow{2}{*}{$\begin{array}{c}\text { Trimester } 3 \\
\text { (181 d to term) } \\
\text { All }\end{array}$} \\
\hline & High & Low & High & Low & \\
\hline Sorghum (kg) & 0.65 & 1.56 & 1.00 & 1.20 & 1.13 \\
\hline Cottonseed meal (kg) & 2.45 & 0.00 & 2.50 & 0.00 & 1.08 \\
\hline Bambatsi hay $(\mathrm{kg})$ & 7.88 & 2.73 & 5.79 & 0.00 & 0.86 \\
\hline Barley straw (kg) & 0.00 & 5.14 & 2.21 & 7.58 & 7.14 \\
\hline Limestone $(\mathrm{kg})$ & 0.07 & 0.02 & 0.12 & 0.06 & 0.08 \\
\hline Premix $\left(\mathrm{kg}^{\mathrm{b}}\right)$ & 0.07 & 0.06 & 0.10 & 0.10 & 0.10 \\
\hline Dry matter intake (DMI) (kg) & 9.95 & 8.64 & 10.51 & 8.10 & 9.39 \\
\hline DMI $(g / k g)$ liveweight ${ }^{\mathrm{c}}$ & 27.81 & 24.67 & 25.91 & 20.18 & 21.23 \\
\hline $\begin{array}{l}\text { Energy, megajoules of metabolisable } \\
\text { energy (MJ ME) }\end{array}$ & 76.29 & 62.54 & 82.43 & 63.14 & 71.45 \\
\hline Energy $(\%) \mathrm{NRC}^{d}$ & 243 & 199 & 229 & 176 & 149 \\
\hline Crude protein (CP) (kg) & 1.37 & 0.41 & 1.40 & 0.38 & 1.06 \\
\hline$C P(\%) N R C^{d}$ & 250 & 75 & 228 & 63 & 135 \\
\hline
\end{tabular}

${ }^{\mathrm{a}}$ Data are presented on as fed basis/heifer per day. ${ }^{\mathrm{b}}$ Premix containing $17 \mathrm{~g}$ calcium, $9 \mathrm{~g}$ phosphorous, $2.91 \mathrm{~g}$ magnesium, $5 \mathrm{~g}$ sulfur, $27200 \mathrm{IU}$ vitamin A, $60 \mathrm{mg}$ vitamin E, $70 \mathrm{mg}$ iron, $150 \mathrm{mg}$ zinc, $100 \mathrm{mg}$ manganese, $55 \mathrm{mg}$ copper, $0.5 \mathrm{mg}$ selenium, $3.4 \mathrm{mg}$ cobalt and $4.2 \mathrm{mg}$ iodine per $100 \mathrm{~g}$. 'Average liveweight at start of trimester. ${ }^{\mathrm{d}}$ Comparison of ration to National Research Council (NRC) (1996) recommended nutrient requirements for pregnant Brangus replacement heifers bred at 23 months with a mature weight of $475 \mathrm{~kg}$ and a calf birth weight of $32 \mathrm{~kg}$. 
1 (Rhinogard Intranasal Vaccine (Live); Q-Vax Pty Ltd, Brookfield, QLD, Australia) and Mannheimia haemolytica (Bovilis MH; Intervet Australia Pty Limited, Bendigo East, VIC, Australia).

\section{Data and sample collection}

Progeny liveweight was measured at regular intervals, blood samples collected at birth (Micke et al. 2010b), 29, 94, 191, 379 and $657 \mathrm{~d}$ (Micke et al. 2010a) and depth of adipose tissue at the rump (P8) and rib (RF) sites measured via real-time ultrasonography (Aloka-500: Aloka, Inc., Tokyo, Japan) using a $20 \mathrm{~cm}$ linear probe at 65, 94, 191, 311, 379, 462, 522 and 657 $\mathrm{d}$. The P8 site is located over the gluteus muscle on the rump, at the intersection of a line through the pin bone parallel to the spine and its perpendicular through the third sacral crest. The RF site was two-thirds of the distance from the dorsal aspect of longissimus dorsi muscle (LD) between the 12th and 13th rib. At slaughter, each animal was killed by captive bolt stunning and exsanguination. Samples of SC at P8 and samples of OM and PR were obtained from each carcass within 20 min of exsanguination, immediately snap frozen in liquid nitrogen and then stored at $-80{ }^{\circ} \mathrm{C}$ until analysis. Standard carcasses (AUS-MEAT 1998) were halved and each side weighed prior to entering the chiller. Carcass weight was calculated as the sum total of the weight of both halves. Assessments of the carcasses were obtained after overnight chilling until the loin temperature was $<11^{\circ} \mathrm{C}$. Fat depth at the P8 and rib sites (AUS-MEAT 1998) were assessed using the Meat Standards Australia (MSA) grading system (MSA 1999).

\section{IGF1, IGF1R, IGF2, IGF2R and LEP mRNA expression in adipose tissue}

The relative expression of IGF1, IGF1R, IGF2, IGF2R and LEP mRNA transcripts in SC, OM and PR adipose tissue of each animal was measured after extraction of total RNA, CDNA synthesis and quantitative real-time PCR (qRT-PCR).

\section{Total RNA extraction and CDNA synthesis}

Total RNA was extracted from SC, OM and PR adipose tissue samples as previously described (Duffield et al. 2008) and total RNA was purified using the RNeasy Mini Kit (Qiagen) as recommended by the manufacturer. Total RNA was quantified by spectrophotometric measurements at 260 and $280 \mathrm{~nm}$. Complementary DNA was synthesized from $5 \mu \mathrm{g}$ of total RNA using Superscript III (Invitrogen) by RT (Gentili et al. 2006). Controls containing no RNA transcript or no Superscript III were used to test for genomic DNA contamination.

\section{qRT-PCR}

The relative expression of IGF1, IGF1R, IGF2, IGF2R and LEP mRNA transcripts in SC, OM and PR adipose tissue of each animal was measured by qRT-PCR using SYBR Green Master Mix in an ABI Prism 7000 Sequence Detection System (Applied Biosystems, Foster City, CA, USA) using bovine-specific primers validated to generate a single transcript as confirmed by the presence of a single double-stranded DNA product of the correct size (Table 4) and sequence confirmed by using a Basic Local Alignment Search Tool (BLAST, www.ncbi.nlm.nih.gov/ blast/Blast.cgi, Bethesda, MD, USA). Each qRT-PCR well contained $5 \mu \mathrm{l}$ Power SYBR Green Master Mix (Applied Biosystems), $1 \mu \mathrm{l}$ each of forward and reverse primer (GeneWorks, Adelaide, SA, Australia) for the appropriate gene (Table 4), $2 \mu \mathrm{l}$ water and $1 \mu \mathrm{l}$ of $50 \mathrm{ng} / \mu \mathrm{l}$ cDNA to give a total volume of $10 \mu \mathrm{l}$. Controls for each primer set containing no cDNA were included on each plate. Three replicates of cDNA from each adipose sample were performed for each gene on each plate. To ensure a consistent result, a quality control (QC) sample was run in triplicate on each plate. Amplification efficiencies were determined from the slope of a plot of $C_{\mathrm{t}}$ (defined as the threshold cycle with the lowest significant increase in fluorescence) against the log of the cDNA template concentration (ranging from 1 to $100 \mathrm{ng} / \mu \mathrm{l}$ ). Comparative cycle threshold values were in the linear amplification range, 16-26 cycles for all genes. The abundance of each transcript

Table 4 Primer sequence for qRT-PCR.

\begin{tabular}{|c|c|c|c|}
\hline Primer name & Sequence (from $5^{\prime}$ to $3^{\prime}$ ) & Final primer concentration $(\mu \mathrm{M})$ & Accession number \\
\hline \multicolumn{4}{|l|}{ IGF1 } \\
\hline Forward & TTGGTGGATGCTCTCCAGTTC & 9.0 & \multirow[t]{2}{*}{ DQ152962 } \\
\hline Reverse & AGCAGCACTCATCCACGATTC & 9.0 & \\
\hline \multicolumn{4}{|c|}{ 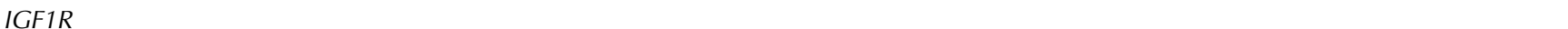 } \\
\hline Forward & AAGAACCATGССТGCAGAAGG & 9.0 & \multirow{2}{*}{ M89789 } \\
\hline Reverse & GGATTCTCAGGTTCTGGCCATT & 9.0 & \\
\hline \multicolumn{4}{|l|}{ IGF2 } \\
\hline Forward & GCTTCTTGССТTCTTGGССТT & 9.0 & \multirow[t]{2}{*}{ AY162434 } \\
\hline Reverse & TCGGTTTATGCGGCTGGAT & 9.0 & \\
\hline \multicolumn{4}{|c|}{ (2) } \\
\hline Forward & GATGAAGGAGGCTGCAAGGAT & 9.0 & \multirow[t]{2}{*}{ AF327649 } \\
\hline Reverse & CСTGATGCCTGTAGTCCAGCTT & 9.0 & \\
\hline \multicolumn{4}{|l|}{ LEP } \\
\hline Forward & ATCTCACACACGCAGTCCGT & 4.5 & \multirow[t]{2}{*}{ NM173928 } \\
\hline Reverse & CCAGCAGGTGGAGAAGGTC & 4.5 & \\
\hline \multicolumn{4}{|c|}{ 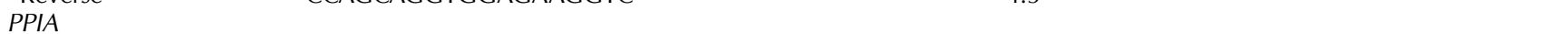 } \\
\hline Forward & ССТGСТТТСАСАGААТААТТССА & 9.0 & \multirow[t]{2}{*}{ BC105173 } \\
\hline Reverse & САTTTGCCATGGACAAGATGCCA & 9.0 & \\
\hline
\end{tabular}


relative to the abundance of the reference gene peptidylprolyl isomerase A (also known as cyclophilin A or PPIA) was calculated using Q-Gene analysis software (Muller et al. 2002).

\section{Plasma leptin}

Concentrations of leptin in progeny plasma were measured at birth, 29, 94, 191, 379 and $657 \mathrm{~d}$ by a competitive ELISA previously described (Kauter et al. 2000). The method is briefly described here. The ELISA plate was coated with $7.5 \mathrm{ng}$ bovine recombinant leptin (brLeptin) in $50 \mu \mathrm{l} 0.1 \mathrm{M}$ bicarbonate buffer (pH 9.0) overnight at $37^{\circ} \mathrm{C}$. The plate was blocked with $200 \mu \mathrm{l}$ $5 \%$ skim milk in ELISA buffer for $1 \mathrm{~h}$ at $37{ }^{\circ} \mathrm{C}$. The sample was added to the well in a volume of $100 \mu \mathrm{l}$ and the antiserum in a volume of $50 \mu \mathrm{l} 10 \%$ Triton-X 100, $0.5 \%$ SDS and $5 \%$ sodium deoxycholate, and the plate was incubated overnight at $37^{\circ} \mathrm{C}$. Streptavidin conjugated to alkaline phosphatase (Amrad Biotech, Boronia, VIC, Australia) was incubated for $1 \mathrm{~h}$ and the plate developed with $p$-nitrophenylphosphate disodium salt hexahydrate. The plate was washed five times between each step with a washing buffer containing $0.9 \%$ saline, $0.05 \%$ Triton $\mathrm{x}$ 100, using a Titertek Microplate washer (Flow Laboratories, Huntsville, AL, USA). Using brLeptin as standard, the assay has a sensitivity of $0.3 \mathrm{ng} / \mathrm{ml}$ with inter- and intraassay variation of 14 and $6.5 \%$ respectively.

\section{Progeny plasma IGF1, IGF2 and total IGF binding proteins}

Concentrations of IGF1, IGF2 and total IGF-binding proteins (tlGFBP) were measured in progeny plasma as previously described (Micke et al. 2010a), by RIA after separation of IGF and IGFBP by size-exclusion HPLC under acidic conditions. Recovery of ${ }^{125}$ I-IGF1 was $90.1 \pm 0.9 \%$ for 11 HPLC runs of progeny plasma. Inter-assay coefficient of variation (CV) for HPLC separation and RIA of IGF1 in progeny plasma was $10.9 \%$ ( $n=18$ assays) and the intra-assay covariance for extraction and assay was $22.0 \%$ for a calf QC sample containing $31.4 \mathrm{ng} / \mathrm{ml}$ of IGF1. Total IGFBP concentrations were measured by analysis of neutralized fraction 1 in the same assay (Carr et al. 1995). Progeny inter-assay CV was $9.7 \%(n=9$ assays) and intra-assay covariance for extraction and assay $21.6 \%$ for a calf QC sample containing $78.0 \mathrm{ng} / \mathrm{ml}$ of IGF2.

\section{Statistical analyses}

Liveweight (Micke et al. 2010a), ultrasonographic measures of P8 and RF depth, P8 and RF depth relative to liveweight and plasma leptin concentrations were analyzed using repeated measures multifactorial ANOVA to determine the effects of maternal nutrition during $\mathrm{T} 1$ and $\mathrm{T} 2$, progeny sex and their interaction terms while including gestation length as a covariate. Relative expression of IGF1, IGF1R, IGF2, IGF2R and LEP mRNA expression in PR, OM and SC adipose tissue, carcass weight and depth of fat at the P8 and RF sites (Micke et al. 2010a) were analyzed by multifactorial ANOVA to determine the effects of maternal nutrition in $\mathrm{T} 1$ and $\mathrm{T} 2$, progeny sex and their interaction terms while including gestation length as a covariate. One-way ANOVA using
Bonferroni adjustment was used to explore significant interactions between maternal nutrition during $\mathrm{T} 1$ and $\mathrm{T} 2$. Bonferroni adjusted correlation analyses were used to calculate the relationships between relative expression of IGF1, IGF1R, IGF2, IGF2R and LEP mRNA in each adipose tissue depot with progeny plasma IGF1, IGF2 and tIGFBP concentrations. Data are presented as mean \pm s.E.M. A probability of $5 \%(P \leq 0.05)$ was accepted as the level of significance and trends reported at $P<0.1$. Data were analyzed using Intercooled Stata 9.0 (StataCorp, College Station TX 77845, USA) software.

\section{Declaration of interest}

The authors declare that there is no conflict of interest that could be perceived as prejudicing the impartiality of the research reported.

\section{Funding}

This work was supported by the Australian Research Council (grant number LP0669781); Meat and Livestock Australia (grant number NBP.343), Australian Agricultural Company (grant number AACo1) and Western Australian Cattle Industry Compensation Fund (grant number CICA2005).

\section{Acknowledgements}

We acknowledge and are grateful for the technical assistance of Ms Shervi Lie, Ms Leewen Rattanatray, Mr Bernard Chuang and the collaboration of Prof. Julie Owen, Drs Kathy Gatford and Jim McFarlane. We are grateful to the Australian Research Council, Meat and Livestock Australia, Australian Agricultural Company, Western Australian Cattle Industry Compensation Fund, Ridley AgriProducts, Milne AgriGroup and Network in Genes and Environment in Development for their support of this work.

\section{References}

AUS-MEAT 1998 AUS-MEAT National Accreditation Standards and Australian Meat Industry Classification System. Brisbane, Australia: AUS-MEAT Ltd.

Bispham J, Gopalakrishnan GS, Dandrea J, Wilson V, Budge H, Keisler DH, Broughton Pipkin F, Stephenson T \& Symonds ME 2003 Maternal endocrine adaptation throughout pregnancy to nutritional manipulation: consequences for maternal plasma leptin and cortisol and the programming of fetal adipose tissue development. Endocrinology 144 3575-3585. (doi:10.1210/en.2003-0320)

Bortolussi G, Mclvor JG, Hodgkinson JJ, Coffey SG \& Holmes CR 2005 The northern Australia beef industry, a snapshot. 2. Breeding herd performance and management. Australian Journal of Experimental Agriculture 45 1075-1091. (doi:10.1071/EA03097)

Carr JM, Owens JA, Grant PA, Walton PE, Owens PC \& Wallace JC 1995 Circulating insulin-like growth factors (IGFs), IGF-binding proteins (IGFBPs) and tissue mRNA levels of IGFBP-2 and IGFBP-4 in the ovine fetus. Journal of Endocrinology 145 545-557. (doi:10.1677/joe.0.1450545)

Cianzio DS, Topel DG, Whitehurst GB, Beitz DC \& Self HL 1982 Adipose tissue growth in cattle representing two frame sizes: distribution among depots. Journal of Animal Science 55 305-312.

Clarke L, Buss DS \& Juniper DS 1997 Adipose tissue development during early postnatal life in ewe-reared lambs. Experimental Physiology 82 1015-1017. (doi:10.1017/S095806709701645X)

Duffield JA, Vuocolo T, Tellam R, Yuen BS, Muhlhausler BS \& McMillen IC 2008 Placental restriction of fetal growth decreases IGF1 and leptin mRNA expression in the perirenal adipose tissue of late gestation fetal sheep. American Journal of Physiology 294 R1413-R1419. 
Ford SP, Hess BW, Schwope MM, Nijland MJ, Gilbert JS, Vonnahme KA, Means WJ, Han H \& Nathanielsz PW 2007 Maternal undernutrition during early to mid-gestation in the ewe results in altered growth, adiposity, and glucose tolerance in male offspring. Journal of Animal Science 85 1285-1294. (doi:10.2527/jas.2005-624)

Gardan D, Gondret F \& Louveau I 2006 Lipid metabolism and secretory function of porcine intramuscular adipocytes compared with subcutaneous and perirenal adipocytes. American Journal of Physiology 291 E372-E380. (doi:10.1152/ajpendo.00482.2005)

Gentili S, Walters MJ \& McMillen IC 2006 Differential regulation of suppressor of cytokine signaling-3 in the liver and adipose tissue of the sheep fetus in late gestation. American Journal of Physiology. Regulatory, Integrative and Comparative Physiology 290 R1044-R1051. (doi:10. 1152/ajpregu.00573.2005)

Greenwood PL, Cafe LM, Hearnshaw H, Hennessy DW \& Morris ST 2006 Long-term consequences of birth weight and growth to weaning on carcass, yield and beef quality characteristics of Peidmontese- and Wagyu-sired cattle. Australian Journal of Experimental Agriculture $\mathbf{4 6}$ 257-269. (doi:10.1071/EA05240)

Gregoire FM 2001 Adipocyte differentiation: from fibroblast to endocrine cell. Experimental Biology and Medicine 226 997-1002.

Gregoire FM, Smas CM \& Sul HS 1998 Understanding adipocyte differentiation. Physiological Reviews 78 783-809.

Hausman GJ, Dodson MV, Ajuwon K, Azain MJ, Barnes KM, Guan LL, Jiang Z, Poulos SP, Sainz RD, Smith S et al. 2009 The biology and regulation of preadipocytes and adipocytes in meat animals. Journal of Animal Science 87 1218-1246. (doi:10.2527/jas.2008-1427)

Holt RIG 2002 Fetal programming of the growth hormone-insulin-like growth factor axis. Trends in Endocrinology and Metabolism 13 392-397. (doi:10.1016/S1043-2760(02)00697-5)

Houseknecht KL, Baile CA, Matteri RL \& Spurlock ME 1998 The biology of leptin: a review. Journal of Animal Science 76 1405-1420.

Kauter K, Ball M, Kearney P, Tellam R \& McFarlane JR 2000 Adrenaline, insulin and glucagon do not have acute effects on plasma leptin levels in sheep: development and characterisation of an ovine leptin ELISA. Journal of Endocrinology 166 127-135. (doi:10.1677/joe.0.1660127)

Kwon H, Ford SP, Bazer FW, Spencer TE, Nathanielsz PW, Nijland MJ, Hess BW \& Wu G 2004 Maternal nutrient restriction reduces concentrations of amino acids and polyamines in ovine maternal and fetal plasma and fetal fluids. Biology of Reproduction 71 901-908. (doi:10.1095/biolreprod.104.029645)

Larson DM, Martin JL, Adams DC \& Funston RN 2009 Winter grazing system and supplementation during late gestation influence performance of beef cows and steer progeny. Journal of Animal Science $\mathbf{8 7}$ 1147-1155. (doi:10.2527/jas.2008-1323)

Louveau I \& Gondret F 2004 Regulation of development and metabolism of adipose tissue by growth hormone and the insulin-like growth factor system. Domestic Animal Endocrinology 27 241-255. (doi:10.1016/j. domaniend.2004.06.004)

McMillen IC \& Robinson JS 2005 Developmental origins of the metabolic syndrome: prediction, plasticity and programming. Physiological Reviews 85 571-633. (doi:10.1152/physrev.00053.2003)

Meat-and-Livestock-Australia 2004 More Beeffrom Pastures: the Producer's Manual. Sydney, Australia: Meat and Livestock Australia Ltd.

Micke GC, Sullivan TM, Gatford KL, Owens JA \& Perry VE 2010a Nutrient intake in the bovine during early- and mid-gestation causes sex-specific changes in progeny plasma IGF-I, liveweight, height and carcass traits. Animal Reproduction Science 121 208-217. (doi:10.1016/j.anireprosci. 2010.05.017)

Micke GC, Sullivan TM, Magalhaes RJS, Rolls PJ, Norman ST \& Perry VEA $2010 b$ Heifer nutrition during early- and mid-pregnancy alters fetal growth trajectory and birth weight. Animal Reproduction Science 117 1-10. (doi:10.1016/j.anireprosci.2009.03.010)

Montague CT, Prins JB, Sanders L, Digby JE \& O'Rahilly S 1997 Depot- and sex-specific differences in human leptin mRNA expression. Diabetes $\mathbf{4 6}$ 342-347. (doi:10.2337/diabetes.46.3.342)

MSA 1999 Grading for Eating Quality - Development of the Meat Standards Australia Grading System, vol 1. Newstead, Australia: Meat Standards Australia.
Muhlhausler BS, Duffield JA \& McMillen IC 2007a Increased maternal nutrition increases leptin expression in perirenal and subcutaneous adipose tissue in the postnatal lamb. Endocrinology 148 6157-6163. (doi:10.1210/en.2007-0770)

Muhlhausler BS, Duffield JA \& McMillen IC $2007 b$ Increased maternal nutrition stimulates peroxisome proliferator activated receptor-gamma, adiponectin, and leptin messenger ribonucleic acid expression in adipose tissue before birth. Endocrinology 148 878-885. (doi:10.1210/ en.2006-1115)

Muller PY, Janovjak H, Miserez AR \& Dobbie Z 2002 Processing of gene expression data generated by quantitative real-time RT-PCR. Biotechniques 32 1372-1379.

Newman R 2007 A Guide to Best Practice Husbandry in Beef Cattle. Branding, Castrating and Dehorning. Sydney, Australia: Meat and Livestock Australia Ltd.

Prins JB 2002 Adipose tissue as an endocrine organ. Best Practice \& Research. Clinical Endocrinology \& Metabolism 16 639-651. (doi:10. 1053/beem.2002.0222)

Robinson DL, Oddy VH, Dicker RW \& McPhee MJ 2001 Post-weaning growth of cattle in Northern New South Wales 3. Carry-over effects on finishing, carcass characteristics and intramuscular fat. Australian Journal of Experimental Agriculture 41 1041-1049. (doi:10.1071/EA00093)

Schut AGT, Gherardi SG \& Wood DA 2010 Emperical models to quantify the nutritive characteristics of annual pastures in south-west Western Australia. Crop and Pasture Science 61 32-43. (doi:10.1071/CP08438)

Smith PJ, Wise LS, Berkowitz R, Wan C \& Rubin CS 1988 Insulin-like growth factor-l is an essential regulator of the differentiation of 3T3-L1 adipocytes. Journal of Biological Chemistry 263 9402-9408.

Soret B, Lee H-J, Finley E, Lee SC \& Vernon RG 1999 Regulation of differentiation of sheep subcutaneous and abdominal preadipocytes in culture. Journal of Endocrinology 161 517-524. (doi:10.1677/joe.0. 1610517)

Stalker LA, Adams DC, Klopfenstein TJ, Feuz DM \& Funston RN 2006 Effects of pre-and postpartum nutrition on reproduction in spring calving cows and calf feedlot performance. Journal of Animal Science $\mathbf{8 4}$ 2582-2589. (doi:10.2527/jas.2005-640)

Sullivan TM, Micke GC, Perkins N, Martin GB, Wallace CR, Gatford KL, Owens JA \& Perry VEA 2009a Dietary protein during gestation affects maternal IGF, IGFBP, leptin concentrations, and fetal growth in heifers. Journal of Animal Science 87 3304-3316. (doi:10.2527/jas.2008-1753)

Sullivan TM, Micke GC \& Perry VEA 2009b Influences of diet during gestation on potential postpartum reproductive performance and milk production of beef heifers. Theriogenology 72 1202-1214. (doi:10.1016/ j.theriogenology.2009.07.016)

Teruel T, Valverde AM, Benito M \& Lorenzo M 1996 Insulin-like growth factor $I$ and insulin induce adipogenic-related gene expression in fetal brown adipocyte primary culture. Biochemical Journal 319 627-632.

Underwood KR, Tong JF, Kimzey JM, Price PL, Grings EE, Hess BW, Means WJ \& Du M 2008 Gestational nutrition affects growth and adipose tissue deposition in steers. Proceedings of the Western Section of the American Society of Animal Science 59 29-32.

Wajchenberg BL 2000 Subcutaneous and visceral adipose tissue: their relation to the metabolic syndrome. Endocrine Reviews 21 697-738. (doi:10.1210/er.21.6.697)

Wallace JM, Regnault TRH, Limesand SW, Hay WWJ \& Anthony RV 2005 Investigating the causes of low birth weight in contrasting ovine paradigms. Journal of Physiology 565 19-26. (doi:10.1113/jphysiol.2004.082032)

Walsh GL \& Birrell HA 1987 Seasonal variations in the chemical composition and nutritive value of five pasture species in south-western Victoria. Australian Journal of Experimental Agriculture 27 807-816. (doi:10.1071/EA9870807)

Yuen BS, McMillen IC, Symonds ME \& Owens PC 1999 Abundance of leptin mRNA in fetal adipose tissue is related to fetal body weight. Journal of Endocrinology 163 R11-R14. (doi:10.1677/joe.0.163R011)

Received 3 August 2010

First decision 13 September 2010

Revised manuscript received 6 February 2011

Accepted 10 February 2011 